\title{
SUSTAINABLE WATER CONSUMPTION IN WATER INTENSIVE TRANSITIVE ECONOMY ${ }^{381}$
}

\author{
Mykhaylo Kunychka ${ }^{382}$ \\ Leonid Raneta ${ }^{383}$
}

https://doi.org/10.31410/itema.2018.1109

\begin{abstract}
Water intensive production is a big challenge for economic and environmental problems in post-soviet transitive economies. Intensity of water consumption differs among the geographical regions of targeted region. The purpose of this paper is to analyze the regional inequalities of water consumption in Ukraine as one of post-soviet republic. To examine water resources issues in targeted country, basic mathematical and statistical tools are applied. In order to examine the sustainability of water consumption by social and environmental factors, we take into account all the administrative units of the country under review and conduct a comparative analysis.
\end{abstract}

Keywords: water resources, water stress indices, transitive economy, Ukraine

\section{INTRODUCTION}

$\mathrm{W}$

ater consumption issues and the scarcity of water resources that are facing the needs of a growing world economy and rapid population growth [4] are increasingly becoming the subject of debate on global policy forums and international organizations such as the United Nations or the World Bank. According to the United Nations Program for Sustainable Development (SDG), clean and affordable water for all is one of the main objectives. Due to poor management and poor infrastructure, millions of people, including children, are dying of illnesses health associated with poor supply of clean drinking water, lack of sanitation and hygiene. The drought affects some of the poorest countries in the world, increasing hunger and malnutrition. Water scarcity and its quality have become one of the priorities of the international community in recent decades. The World Bank and the UN have expressed their commitment to meeting the sustainable development goals by 2030 and the issue of water resources is a priority not only in the poorest regions of the world.

For many countries suffering from scarcity of water resources, these problems have come to the forefront. Countries with a shortage of water resources are potential sources of international and regional instability, which implies an economic, political and social (environmental) dimension. Post-Soviet space is no exception and has several examples of political tension caused by the use of water resources. Water disputes involving the Aral Sea, the rivers Amu Darya and Son Darya [10], water shortages in the conflict region of Donbas [5] are not the only cases of waterborne tensions in the former USSR republics.

\footnotetext{
381 This paper is the part of research project for young researchers no. I-18-104-00 "Environmental issues and development in transitive economies with high water intensity"

382 University of Economics in Bratislava, Dolnozemská cesta 1, 85235 Bratislava, Slovakia

${ }^{383}$ University of Economics in Bratislava, Dolnozemská cesta 1, 85235 Bratislava, Slovakia
} 
In this paper, we emphasize social and environmental aspects of water consumption. The aim of this article is to analyze regional aspects of water resources and their consumption in Ukraine. In order to examine the sustainability of water consumption by social and environmental factors, we take into account all the administrative units of the country under review and conduct a comparative analysis.

\section{EVALUATION OF WATER SCARCITY AND STRESS}

Assessing water scarcity and sustainability often involves obscure social, economic or policy factors that are sometimes complicated to quantify. Assessing sustainability and water scarcity is a difficult task to make when deciding on water management, or implementing water management policies or monitoring. For these reasons, a successful evaluation of measures for sustainable use of water resources is a difficult and sometimes impossible goal [8]. Nevertheless, in the last decades, when water issues have become a popular agenda on the platform of international organizations, many indicators where developed to assess the scarcity and sustainable use of water.

One of the basic water scarcity measures is the Falkenmark indicator, which is defined as the total annual runoff of water available for consumption in a particular region or country [1]. The Falkenmark water stress indicator allows us to determine the available volume of water consumption per capita in a particular region and compare the values obtained with certain critical values [3]. The water stress index defines two thresholds. There is water stress in the region if the annual volume of water per person is less than $1700 \mathrm{~m}^{3}$. An indicator of less than $1000 \mathrm{~m}^{3}$ per inhabitant per year indicates that the region or country has a shortage of water [2]. With an annual runoff of $1000 \mathrm{~m}^{3}$ per capita in Ukraine, it is possible to refer to it as a water stress landscape.

The Falkenmark water stress indicator reflects only water reserves without taking into account the real needs of water resources implicitly. The indicator does not reflect specific economic and social structures of different regions and countries. When calculating the water resource vulnerability index [7] a slightly different approach is used, which is calculated as a ratio of total annual usage to available water resources [1]. To some extent, the vulnerability index reflects the change in demand for water.

Brown and Matlock [1], for example, summarize five different approaches to assessing water scarcity. It includes indicators based on population requirements, vulnerability indexes for water resources, indexes containing the environmental dimension of water resources utilization. Measurements of sustainable use of water resources include indices such as water poverty index, environmental performance indicator, water sustainability index [8], etc. These water sustainability indicators usually include several dimensions with opposite characteristics such as the economy and the environment. For example, the water poverty index [9] should reflect five aspects of water supply, including reserves, access to water resources, the socio-economic situation in the region, sectoral consumption and environmental characteristics of water use. Aggregated measurements do not always allow adequate assessment of water scarcity, because they do not include unequal distribution of resources and consumers in a particular region [3]. Assessment of water scarcity and sustainability often requires different types of costs and encompass obscure social, economic or political factors that are sometimes complicated to measure or quantify. The evaluation of water sustainability and scarcity becomes a hard task for decision-making, water management, implementation of water policies or monitoring [8]. 
In the past few decades, when water issues became a popular agenda on the platform of international organizations, many indices and indicators where developed in order to assess water scarcity and sustainable water usage.

\section{DATA AND METHODOLOGY}

For a more complete understanding of the environmental and economic situation that arose after 26 years of independent economic activities of the selected case, we are conducting a brief analysis of the current state of water resources and the perspective of its further usage based on the principles of sustainable development. Various environmental and social variables where selected to control the various factors of sustainable development, reflecting the current state of water resource utilization with regard to the environmental burden of water usage.

Sustainability indicators are definitely elements of information that reflect the state of the system by which we can better understand the full picture of the current state of the selected system and explore the direction of the development of the target social or environmental complex. Indicators of sustainable development are a method for determining the future development of a particular system. The development of such a criterion is essential for the decision making and consideration of the environmental factor in the development of the region of the country as a whole. The issue of sustainable economic development and water consumption is particularly important in the context of the achievement of the SDGs set by the international community in the UN Resolutions of 2015.

To investigate the sustainability of water resource usage at regional level, we apply a revised Sustainable Water Consumption criterion [11], including environmental and social criteria for assessing the sustainability of water resource usage in selected regions of the target country. The criterion helps evaluating the social and environmental problems of water usage, and allows the comparison of selected administrative units of the state under review according to the environmental and social efficiency of water consumption. The applied criterion makes it possible to identify discrepancies between the regions. In addition, standard methods of mathematical and econometric analysis, including cluster analysis, where applied to achieve the objectives of the paper.

To assess the sustainability of water use in a particular administrative unit, we also need to count on the environmental effectiveness. Environmental efficiency is calculated as the quantity of discharged water that does not meet the quality in accordance with environmental safety standards. The environmental criteria are defined as the proportion of cleaned discharged water in the total volume of discharged water $(K e n v)$. Social efficiency is a more complex indicator that is complicated to measure and compute. Reflecting the sustainable water consumption this criterion deals with the minimization of water usage in order to meet the needs of society. To determine the social efficiency of water consumption we use the ratio of indicators such as average country value of water consumption per capita and water consumption per capita in particular administrative region $(K s o c)$. All water consumption and discharged water data was obtained from annual national report of Ministry of ecology and natural resources of Ukraine [6].

Data on volumes of consumption and water consumption are expressed in millions of cubic meters. Gross national product was collected from the regional statistical database of the State Statistical Service of Ukraine. Transformation of regional product values was also needed as all data is only available in the national currency of the country under review. 


\section{RESULTS AND DISCUSSION}

The data for our calculations are presented in the Table 1. It shows the heterogeneity of the regions of Ukraine. We can emphasize the four groups of regions that represent extremes and, at the same time, they are valuable for interpreting the results. Table 1 shows the available information for all regions of Ukraine.

The regional distribution of water usage, in the Table 1, shows the differences in overall amounts of water discharged into the environment (water discharge) and the extent of pollution (Discharged untreated and insufficiently treated). Water consumption in absolute numbers is concentrated (up to 65\%) in a relatively few industrial or agrarian regions of Ukraine (Dnipropetrovska, Donetska, Zaporizhska, Kyjivska, City of Kyjev). The same applies for the main polluting regions (Dnipropetrovska, Donetska) where up to $65 \%$ of untreated and insufficiently treated water was discharged.

Table 1: Water usage and discharge in Ukraine (2014), thousands $\mathrm{m}^{3}$

\begin{tabular}{|c|c|c|c|c|c|c|}
\hline & $\begin{array}{c}\text { Water usage, } \\
\text { m3/person }\end{array}$ & $\begin{array}{c}\text { Water } \\
\text { discharge }\end{array}$ & $\begin{array}{c}\text { Discharged } \\
\text { (untreated) }\end{array}$ & $\begin{array}{c}\text { Discharged } \\
\text { (insufficiently } \\
\text { treated) }\end{array}$ & $\begin{array}{c}\text { Discharged } \\
\text { (normatively } \\
\text { pure) }\end{array}$ & $\begin{array}{c}\text { Discharged } \\
\text { (normatively } \\
\text { treated) }\end{array}$ \\
\hline Ukraine & 188,78 & 6354 & 175 & 748 & 4015 & 1416 \\
\hline Vinnycka & 68,30 & 70 & 0,2 & 1 & 41 & 28 \\
\hline Volynska & 63,28 & 44 & 1 & 0 & 17 & 26 \\
\hline Dnipropetrovska & 414,75 & 1123 & 119 & 193 & 727 & 84 \\
\hline Donetska & 124,96 & 914 & 6 & 290 & 518 & 100 \\
\hline Zhytomyrska & 125,00 & 159 & 0 & 3 & 123 & 33 \\
\hline Zakarpatska & 23,82 & 31 & 0 & 2 & 1 & 28 \\
\hline Zaporizhska & 648,95 & 807 & 2 & 71 & 680 & 54 \\
\hline Ivano-Frankivska & 66,54 & 73 & 0 & 1 & 25 & 47 \\
\hline Kyjivska & 467,26 & 724 & 0 & 2 & 674 & 48 \\
\hline Kirovohradska & 94,84 & 90 & 0 & 4 & 65 & 21 \\
\hline Luhanska & 39,19 & 53 & 1 & 29 & 12 & 11 \\
\hline Lvivska & 59,50 & 215 & 1 & 44 & 20 & 150 \\
\hline Mykolajivska & 187,23 & 125 & 0 & 24 & 100 & 1 \\
\hline Odeska & 113,08 & 206 & 28 & 22 & 63 & 93 \\
\hline Poltavska & 147,69 & 194 & 0 & 4 & 148 & 42 \\
\hline Rivnenska & 147,27 & 112 & 0 & 7 & 72 & 33 \\
\hline Sumska & 89,01 & 49 & 0 & 20 & 22 & 7 \\
\hline Ternopilska & 67,29 & 70 & 1 & 2 & 48 & 19 \\
\hline Harkivska & 113,13 & 299 & 6 & 5 & 84 & 204 \\
\hline Hersonska & 993,56 & 56 & 1,2 & 0 & 33 & 23 \\
\hline Hmelnytska & 53,79 & 29 & 1 & 1 & 3 & 24 \\
\hline Cherkaska & 163,76 & 165 & 2 & 3 & 114 & 46 \\
\hline Chernivetska & 87,92 & 61 & 2 & 1 & 39 & 19 \\
\hline Chernihivska & 134,51 & 101 & 0 & 19 & 77 & 5 \\
\hline City of Kyjev & 192,18 & 584 & 5 & 0 & 309 & 270 \\
\hline
\end{tabular}

The water consumption per capita is also heterogeneous. In four regions of Ukraine (Dnipropetrovska, Zaporizhska, Kyjivska, Hersonska) the water usage per capita is two times higher than the Ukraine average. Hersonska region has the extremes values of water usage per capita because it has vast agrarian irrigations systems. This is also the reason why Hersonska does not discharge vast amounts of untreated and insufficiently treated water.

In accordance with the methodology stated in the section above, we made the calculations of disaggregated coefficients that allow us the comparison of the regions by the means of cluster analysis. The methodology of cauterisation allows the determination of extreme values and 
problematic regions for policy creation and addressing the critical cases of water pollution and consumption of water resources. Both coefficients are calculated so that their values have the same logic of interpretation (in our case the higher the value the better performance of a selected region).

Figure 1: Relationship between environmental and social indicator

Cluster Scatterplot

Ward's Method,Euclidean

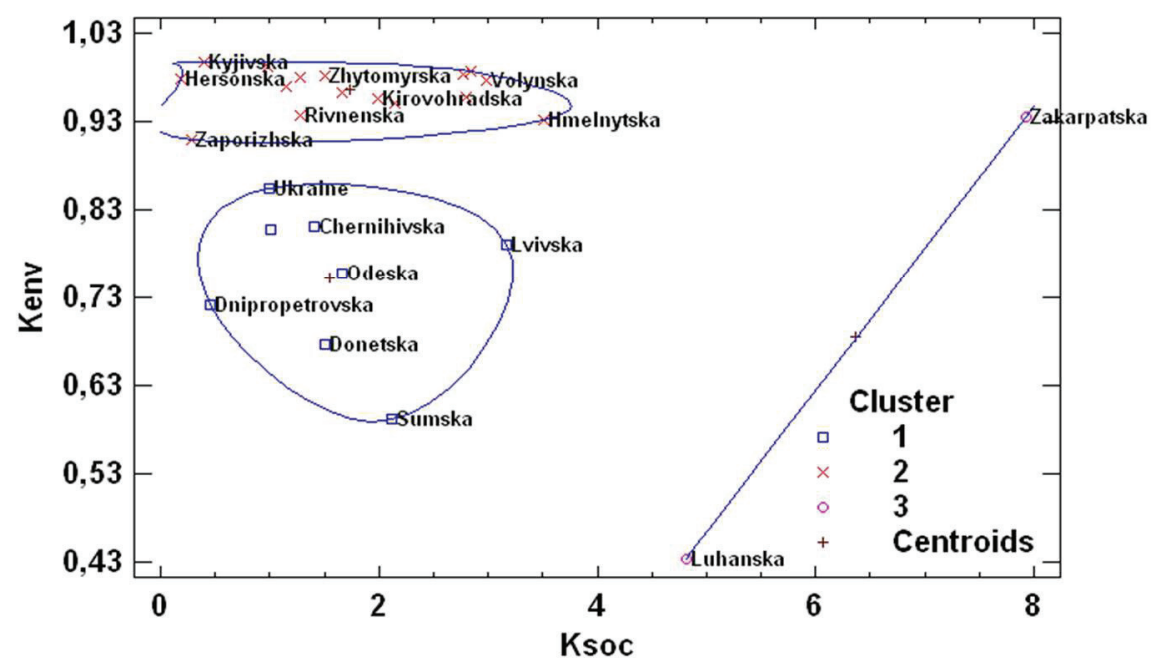

The division into three main clusters allows grouping the regions by their similarity. The first cluster groups the regions that achieve low levels of pollution and their environmental footprint is low. Simultaneously this group of regions has a high variability of consumption per capita. The second cluster groups the relatively more polluting regions. This cluster is discharging absolutely the biggest amounts of untreated and insufficiently treated water. From the policy making point of view these regions are in need of actions and projects for improvement of their filtration capacities. Prioritization should be directed from the bottom of this cluster up (Luhanska, Sumska and up). The third cluster is grouping the extreme readings. Zakarpatska and Luhanska regions have the lowest values in their water consumption per capita relatively to the Ukraine average. In addition, at the same time both of these regions are in the extreme positioning in pollution. Zakarpatska has one of the smallest environmental footprints and Luhanska is positioned on the other side of the distribution being relatively the most polluting, having only $43 \%$ of the discharged water normatively treated.

\section{CONCLUSION}

The economy of Ukraine quite extensively uses natural resources both energy and water, which is caused by the historical development of the previous stage of industrialization. Environmental problems, such as ignoring ecological balance and pollution of water resources, have become part of the agenda of the newly created state. During the last years of the independence of Ukraine, the intensity of water use in the Ukrainian economy gradually declined, but still high enough. Our findings highlighted the differences in the use of water resources in the individual regions of Ukraine. Internal regional heterogeneity is manifested not only in the economic sphere but also in the environmental sphere. Our findings show that the dispersion in the indicators of the use of water resources is substantial and expressed in multiples. A similar situation is in the case of ecological burdens. 
However, making water use more effective is very desirable because the water use rate in Ukraine is relatively high compared to European and other post-Soviet economies. Particular attention should be paid to increasing the efficiency of water use in the industrial complex. In the context of the above statements, an important issue is also the introduction of new economic regulation tools for the better and more efficient use of water resources. Also relevant could be the introduction of economic incentives for the efficient use of water resources and the implementation of the modernization of industrial technological systems.

\section{REFERENCES}

[1] Brown, A., Matlock, M. D. (2011) A review of water scarcity indices and methodologies. White paper 106.

[2] Falkenmark, M., Lundqvist, J., Widstrand, C. (1989). Macro-scale water scarcity requires micro-scale approaches. Natural resources forum, 4 (13), pp. 258-267.

[3] Freedman, A. A. (2012) Modeli ekonomicheskovo upravlenija vodnymi resursami. Vysshaja shkola ekonomiki, Moscow. 288 p.

[4] Gress, M. (2010) Populácia v rozvojových krajinách. Ekonom, Bratislava, 57 p.

[5] Kunychka, M., Orlando, L., Raneta, L. (2017). Water Intensive Economy and Environmental issues in the Post-Soviet Transition Country. International Journal of Ecology \& Development, 32(2), pp. 81-94.

[6] Ministry of ecology and Natural resources of Ukraine (2014): National report on the state of environment in Urkraine in 2014. pp. 52-95.

[7] Raskin, P. et al. (1997) Water futures: assessment of long-range patterns and problems. Comprehensive assessment of the freshwater resources of the world. Environment Institute, Stockholm.

[8] Russo, T., Alfredo, K., Fisher, J. (2014) Sustainable water management in urban, agricultural, and natural systems. Water, 6(12), pp. 3934-3956.

[9] Sullivan, C. A., Meigh, J. R., Giacomello, A. M. (2003) The water poverty index: development and application at the community scale. Natural resources forum, 27(3), pp. 189-199.

[10] Vinogradov, S. (1996) Transboundary water resources in the former Soviet Union: between conflict and cooperation. Natural Resources Journal, pp. 393-415.

[11] Vystavna, Y.Y., Grynenko, V.V. (2007) Ocinka stijkosti vodokorystuvanna v regionach Ukrajiny, Kommunalnoje chozajstvo gorodov, pp. 155-163. 